\title{
MODIFIED WAALER-ROSE REACTION EMPLOYING SENSITIZED HUMAN CELLS
}

BY

\author{
H. J. GIBSON AND N. R. LING \\ From the Bath Area Clinical Laboratories
}

(RECEIVED FOR PUBLICATION MAY 28, 1956)

The Waaler-Rose test (Waaler, 1940; Rose, Ragan, Pearce, and Lipman, 1948) has established itself as a laboratory procedure of limited value in the diagnosis of rheumatoid arthritis. With a few exceptions the workers who have used it find it to be positive in under 75 per cent. of cases of that disease. It is rarely positive in other conditions, except disseminated lupus erythematosus and hepatitis. Its importance appears to lie in the fact that it is independent of non-specific plasma protein changes which give the raised erythrocyte sedimentation rate, increased plasma viscosity, positive serum colloidal gold reaction, positive formol-gel test, and abnormal electrophoretic pattern not only in rheumatoid arthritis but in many other chronic diseases. The test has a relative specificity which leads to the hope that with a fuller understanding of its underlying principles a "break through" may be established in the problem of aetiology.

Many modifications have been introduced, but they have been mainly concerned with that part of the reaction represented by the patient's serum and the general conditions under which it reacts. An early refinement was the preliminary absorption of the serum by unsensitized sheep cells to remove natural anti-sheep haemolysin (Heller, Jacobson, and Kolodny, 1949). Attempts to isolate the active principle of the positive serum by fractionation have been numerous. Thus Svartz and Schlossmann (1953) claimed a high specificity for the cold-euglobulin fraction, and Robinson, Stulberg, and Kuyper (1954) and Ziff, Brown, Badin, and McEwen (1954), using the method of dialysis against solutions of low ionic strength, obtained the active principle in the euglobulin precipitate. Wager and Alameri (1953) also noted the low solubility of the factor. Hobson and Gorrill (1952) presented evidence that the agglutinating principle might be a thermostable complement fraction, and, by inference, suggested the ammoniainactivable fourth component C 4. Heller, Jacobson,
Kolodny, and Schuman (1952) and Heller, Kolodny, Lepow, Jacobson, Rivera, and Marks (1955) found that various normal animal sera potentiated thei reaction, and they devised a test using 5 per cent $\vec{\sigma}$ (later 2 per cent.) sheep serum as diluent. Sheep? serum was chosen as the most active of the animal species tested and not because the cells used weres from that species. They made the important claim? that under these conditions the strength of the $\stackrel{\mathbb{D}}{\stackrel{D}{3}}$ reaction with normal sera was not dependent on the concentration of rabbit $v$. sheep amboceptor used to sensitize the cells as is the case with serigmes from rheumatoid cases. A four-fold or greater increase of titre in rheumatoid sera was noted whing serum diluent as compared with saline diluent? Heller and others (1955) also employed Cohn's ethanol fractionation procedures in the analysis on the patient's serum effect and found that activityo resided in Fraction III and probably in the beta liproprotein part of that fraction. Heller, Jacobson Kolodny, and Kammerer (1954) made a further advance in technique by adsorbing Fraction IE ( $\gamma$-globulin) from normal human serum on tanned. sheep red cells and found that this could be substi-⿳亠丷厂巾 tuted for the red cell-amboceptor system in a modified Rose test. An inhibitory factor in norma serum euglobulin absent from the serum of casesi of rheumatoid arthritis, including those in which Waaler-Rose test is negative, has been demonstratedo by Ziff and others (1954), who suggest that failure of the euglobulin to inhibit is a more sensitive? indicator of the presence of agglutinating factor than the direct test. Heller and others (1954) alsoos demeasstrated an inhibitory effect following tho addition of pooled Fraction II ( $\gamma$-globulin) to positively reacting rheumatoid sera.

It has seemed to us that the test might be approached from the point of view of the "antigen"? In its original form, the Rose test employed bios? logical reagents from three species: sheep, rabbit, 
and man. Rabbit and human sera may contain many reactive antigens and antibodies, and the serological system produced is thus of the utmost complexity.

The present work is concerned with the use of sensitized human red cells instead of the more usually employed sheep cells. In this way the species derivation of reagents could be cut down to two. It was felt that this simpler system would lend itself more readily to an analysis of the factors concerned. Hobson and Gorrill (1952) used sensitized guinea-pig and mouse cells in addition to those of sheep and obtained identical end-titres.

Winblad (1952) found that sensitized ox and horse cells gave a positive reaction, and Pike, Sulkin, and Coggeshall (1949) had employed ox and goat red cell systems successfully although human group-O red cells sensitized with homologous amboceptor were not agglutinated by one positive serum tested. Loghem-Langereis (1950, quoted by Jochem, Eyquem, and Jacqueline, 1955) was unsuccessful with a human red cell, rabbit anti-human system. Wager (1950), on the other hand, demonstrated that human Group-O cells could be substituted for sheep cells in the test and that the patient's own cells would also give the reaction. Dickgiesser and Harter (1953) reported that a potent anti-human red cell sensitizer could be prepared by immunizing rabbits with papain-treated human cells. Horse immune anti-human-red-cell serum has also been shown to be an effective sensitizer (Jochem and others, 1955). The general properties of the sensitized human red cell system in the Rose test have not hitherto been examined.

\section{Materials and Methods}

Patient's Serum.-All sera were stored at $4^{\circ} \mathrm{C}$. and inactivated before use at $56^{\circ} \mathrm{C}$. for 30 minutes. Storage over long periods was in the frozen state at $-20^{\circ} \mathrm{C}$. Controls were obtained from general medical and orthopaedic cases and from laboratory staff. Sera were tested by the original Rose technique in the routine clinical laboratory of the Royal National Hospital for Rheumatic Diseases employing sheep cells (Burroughs Wellcome) washed three times in normal saline and sensitized with one quarter of the minimal agglutinating dose (M.A.D.) of rabbit $v$. sheep serum (Difco).

Sensitized Human Red Cells.-A rabbit was immunized with Group-O Rh-negative cells from one of us (H.J.G.). The cells were collected in Alsever's solution and washed three times. The course consisted of seven intraperitoneal injections of $1 \mathrm{ml}$. and two intravenous injections of $5 \mathrm{ml}$. at two- or three-day intervals. When the titre was satisfactory (agglutination at 1 in 10,000 ) the animal was bled out by heart puncture under anaesthesia. $45 \mathrm{ml}$. of serum were obtained. This was stored, partly as a working solution in 50 per cent. glycerol at $4^{\circ} \mathrm{C}$., and the remainder frozen at $-20^{\circ} \mathrm{C}$. For the test, human cells were washed and sensitized with one-quarter of the minimal agglutinating dose in a one per cent. red cell suspension. The original donor's cells were used except when the patient's cells were under test.

Haemagglutination Tests with Human Sera.-These were carried out exactly as in the original Rose test with doubling dilutions of the serum from 1 in 8 to 1 in 4,096 (final dilutions after adding red cell system). Tests were incubated for one hour at $37^{\circ} \mathrm{C}$. and left overnight at $4^{\circ} \mathrm{C}$. After a short period of incubation at $37^{\circ} \mathrm{C}$. to exclude cold-agglutinins, tubes were shaken to read the end-point, which was shown by the presence of granules just visible to the naked eye. A check reading in doubtful cases can be usefully made after a further 15 minutes on the bench when normal sedimentation in negative tubes is commencing and a granular deposit in positive tubes is readily seen.

Fractionation of Human Sera.-The euglobulin method of Ziff (1954) was followed, except that no preliminary absorption was necessary. It was found that inactivation might be carried out before or after dialysis without difference to the result.

\section{Results}

When human red cells were sensitized with rabbit $v$. human amboceptor they could be used as a reagent in the Waaler-Rose test and appeared to give very similar results to those obtained with the sensitized sheep-cell reagent. Table I (overleaf) exemplifies the results. The end-titre obtained with human cells was usually very close to that of the classical Waaler-Rose reaction. In the example chosen in Table I, the serum was a strong reactor with a D.A.T. of 256 . The end-titre with human cells proved to be exactly the same as that with sensitized sheep cells. In some tests human cells gave a higher result, in others lower, but the difference was rarely more than two tubes.

The patient's own cells were an equally efficient reagent, and in such a reaction all question of natural, or iso-antibodies could be excluded. It is of interest that the sensitized cells of the patient were fully agglutinable after washing, because in this reaction the only antigenically foreign material is the adsorbed haemagglutinating antibody. The patient's serum has been tested against his own sensitized cells in ten cases.

\section{Comparison of Sheep and Human Sensitized Red Cells as Reagents}

(1) Correlation with Results of Sensitized Sheep Cell Reactions. At this stage it has not been possible to undertake a large-scale correlation between the clinical condition and the human red cell reaction. 
TABLE I

COMPARISON OF AGGLUTINATION TESTS WITH SHEEP, HUMAN, AND PATIENT'S OWN RED CELLS, AND EFFECT OF WASHING

\begin{tabular}{|c|c|c|c|c|c|c|c|c|c|c|c|}
\hline \multirow{2}{*}{ Cells } & & \multicolumn{9}{|c|}{ Dilution of Patient's Serum (Case of Active Rheumatoid Arthritis) } & \multirow{2}{*}{ 4,096 穴 } \\
\hline & & $1: 8$ & 16 & 32 & 64 & 128 & 256 & 512 & 1,024 & 2.048 & \\
\hline \multirow{2}{*}{ Sheep } & Sensitized .. & +++ & $+t+$ & +++ & $+t+$ & +++ & $++t$ & +++ & $++t$ & + & $-\frac{0}{\bar{c}}$ \\
\hline & Unsensitized & + & - & - & - & - & - & - & - & - & - \\
\hline \multirow{2}{*}{$\begin{array}{l}\text { Human } \\
\text { (H.J.G.: O Rh Negative) }\end{array}$} & Sensitized ... & $++t$ & $+t+$ & +++ & +++ & +++ & $+t+$ & $+t+$ & +++ & + & - \\
\hline & Unsensitized & - & - & - & - & - & - & - & - & - & - \\
\hline \multirow{2}{*}{ Human (Patient) } & Sensitized .. & +++ & $+t+$ & $+t+$ & $++t$ & +++ & $+t+$ & $+t+$ & $++t$ & + & - \\
\hline & Unsensitized & - & - & - & - & - & - & - & - & - & - \\
\hline Human (Patient) & $\begin{array}{l}\text { Sensitized } \\
\text { and Washed }\end{array}$ & $++t$ & $++t$ & $+t+$ & +++ & $+t+$ & $++t$ & $+t+$ & $+t+$ & + & - \\
\hline
\end{tabular}

It was thought more informative to correlate the sheep-cell with human-cell results, because there is already an extensive literature, reviewed by Bunim, Sokoloff, Williams, and Black (1954), relating the former to rheumatoid arthritis, lupus erythematosus, hepatitis, and other diseases. In all, one hundred specimens have been tested in parallel by the two methods. The results (Table II) show a high degree of correlation. Where disagreement is present the figures show a slightly higher sensitivity in the human cell test. In the original Rose test a differential titre of 16 occupies a zone between positive and negative and it is of interest that the human cell test gives both positive and negative results at this titre.

TABLE II

CORRELATION BETWEEN HUMAN AND SHEEP CELL TESTS ON 100 PATIENTS' SERA

ALL CLINICAL GROUPS

\begin{tabular}{|c|c|c|c|}
\hline \multirow{2}{*}{$\begin{array}{c}\text { Sensitized Sheep } \\
\text { Cells } \\
\text { D.A.T. }\end{array}$} & \multicolumn{3}{|c|}{ Sensitized Human Cells } \\
\hline & Positive 1 in 8 & Negative & Total \\
\hline $\begin{array}{l}\text { Negative }(<1: 8) \ldots \\
\text { Borderline }(16) \\
\text { Positive }(>1: 16) \ldots\end{array}$ & $\begin{array}{r}2 \\
7 \\
39\end{array}$ & $\begin{array}{r}46 \\
6 \\
0\end{array}$ & $\begin{array}{l}48 \\
13 \\
39\end{array}$ \\
\hline Total Sera & 48 & 52 & 100 \\
\hline
\end{tabular}

(2) Distribution in Serum Fractions.-Further evidence that the tests are basically the same is given in Table III, in which positively reacting and normal sera were compared before and after fractionation. The two human-cell systems gave the same results throughout, the euglobulin fraction being as powerful as the whole serum. The fall in titre for sheep cells is not significant, other experiments frequently showing an equal titre.
TABLE III

AGGLUTINATION REACTIONS USING EUGLOBULIN FRACTIONS OF RHEUMATOID AND NORMAL SERA WITH HUMAN AND PATIENT'S CELLS

\begin{tabular}{|c|c|c|c|c|}
\hline \multirow[b]{2}{*}{$\begin{array}{l}\text { Sensitized Cells } \\
\quad(\$ \text { M.A.D. })\end{array}$} & \multicolumn{2}{|c|}{ Serum of Patient E } & \multicolumn{2}{|c|}{ Normal Serum } \\
\hline & $\begin{array}{c}\text { Reciprocal } \\
\text { Titre of } \\
\text { Whole } \\
\text { Serum }\end{array}$ & $\begin{array}{l}\text { Reciprocal } \\
\text { Titre of } \\
\text { Euglobulin }\end{array}$ & $\begin{array}{l}\text { Reciprocal } \\
\text { Titre of } \\
\text { Whole } \\
\text { Serum }\end{array}$ & $\begin{array}{c}\text { Reciprocal } \frac{\mathbb{Z}}{2} \\
\text { Titre of } \\
\text { Euglobulin }\end{array}$ \\
\hline $\begin{array}{l}\text { Human (H.J.G.) } \\
\text { Patient E } \\
\text { Sheep* .. }\end{array}$ & $\begin{array}{l}2,048 \\
2,048 \\
2,048\end{array}$ & $\begin{array}{l}2,048 \\
2,048 \\
1,024\end{array}$ & $\begin{array}{l}0 \\
0 \\
8\end{array}$ & 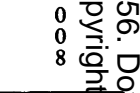 \\
\hline
\end{tabular}

* In tests using sheep cells, sera were absorbed by unsensitizec sheep cells before testing.

(3) Absorption of the Serum Principle reacting with Sensitized Human Cells.-Absorption by unsensitized human cells did not influence the patient's serum titre. Sensitized cells gave somet evidence of an absorption effect, but it was achieved only with difficulty. Multiple serial absorptions of the same sample of human positive serum were tried, $2 \mathrm{ml}$. of packed sensitized human cells were added to $4 \mathrm{ml}$. of positive serum and were allowe to interact at $37^{\circ} \mathrm{C}$. for one hour and left overnigh at $4^{\circ} \mathrm{C}$. The serum was separated and an aliquog tested for agglutinating activity. The remaindes was reabsorbed in the same way and again tested? Table IV (opposite) shows the results of an experimen in which three absorptions were carried out. The titre fell from 256 to 64 . Some of this fall mads have been due to dilution in the absorbing process

The effect of varying the sensitizing dose was the tested. Human cells were used, unsensitized, and sensitized by one-tenth, one-quarter, and on minimum agglutinating dose of the homologous antiserum. Absorption of a known positive serung 
TABLE IV

MULTIPLE SERIAL ABSORPTIONS OF SAME SAMPLE OF ROSE POSITIVE SERUM BY SENSITIZED HUMAN RED CELLS

(Red cells sensitized by M.A.D. ambocepter)

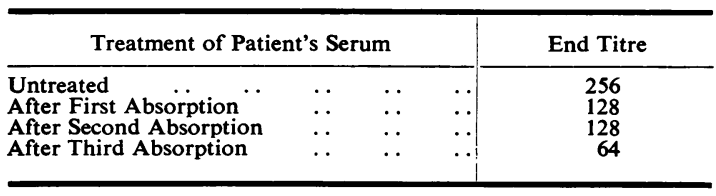

was carried out overnight at $4^{\circ} \mathrm{C}$. with an equal volume of packed sensitized human cells. The results are shown in Table $\mathrm{V}$.

TABLE V

EFFECT OF ABSORPTION OF RHEUMATOID SERUM WITH SENSITIZED HUMAN CELLS ON WAALER-ROSE TITRE

\begin{tabular}{c|c}
\hline $\begin{array}{c}\text { Sensitizing Dose ( } \times \text { M.A.D.) on } \\
\text { Cells used for Absorption* }\end{array}$ & Titre of Rheumatoid Serum \\
\hline Nil & 128 \\
$0 \cdot 1$ & 64 \\
$0 \cdot 25$ & 32 \\
$1 \cdot 0$ & 16
\end{tabular}

* Absorption was performed overnight at $4^{\circ} \mathrm{C}$. with an equal volume of packed human cells sensitized with the stated fraction of the minimum agglutinating dose (M.A.D.).

Absorption in all cases was incomplete, but the reduction in serum titre ran parallel with the sensitizing dose of amboceptor. This finding recalls the conclusion of Heller and others (1954) that the sensitizing substance acts in the context of these procedures as antigen and the agglutinating factor in a rheumatoid sera as antibody. The point is one of cardinal importance in the understanding of the mechanism of the test and further work is required. The difficulty of effecting absorption of the reactive principle has been previously noted in tests with sheep cells by Waaler (1940), Winblad (1952), Pike and others (1949), and Tawil and Abd el Wahab (1955). Heller and others (1954) were able to absorb "agglutinins" for cells sensitized by both amboceptor and Fraction II by treating the serum with Fraction II-sensitized cells. The effect on the efficiency of absorption of increasing the sensitizing dose was noted by Wager (1950) and Pike and others (1949) in the case of the sheep-cell reaction.

\section{Discussion}

Sensitized human cells form a suitable reagent for the Waaler-Rose test, and the patient's own cells may be used. By this means the system is simpler from a serological point of view, as an antigenically foreign biological reagent has been eliminated. From a number of tests carried out, the humancell system appears to give very similar results to those obtained with sheep cells. We find no evidence that any spectacular increase in the incidence of positive reactions in rheumatoid arthritis will be found with human cells.

The use of patient's cells for a modified WaalerRose test has certain advantages. It requires only preserved anti-human haemagglutinating serum and patient's clotted blood. The red cells, the most labile of the reagents used in the test, can be of known freshness, and preliminary absorption of patient's serum is unnecessary. At present, however, the modification is not put forward as a routine procedure to replace the standard test, but rather as a research tool for the investigation of the principles underlying it.

Our results strongly suggest that the serum factor reacting with sensitized human Group-O or with the patient's own cells is the same as that which reacts with sensitized sheep cells in the classical Waaler-Rose test. From a consideration of the literature of this test, the fundamental question is whether the agglutinin-activating factor is a true serological reagent of antibody type or a substance with biochemical activity resembling an enzyme. It is towards the solution of this problem that the human red cell system is proposed. When the patient's own washed sensitized cells react with his own serum, the serological system is a relatively simple one. The only foreign protein is the adsorbed antibody globulin which could act as "antigen" in the test. It has, however, been shown by others that amboceptors derived from guinea-pig and horse are equally effective in sensitizing sheep cells for the test, and it may be presumed that these animal species could also provide specific anti-human red-cell sensitizers with the same effects. We are, therefore, faced with the necessity of postulating an "antibody" in rheumatoid arthritis capable of reacting with the adsorbed antibody globulin of a variety of animal species. If such a remarkable polyvalency is to be proved, or if, alternatively, a common antigen is to be demonstrated in antibody globulins of a variety of unrelated animal species, the simplest possible reacting system is desirable. We wish to emphasize the value of a human Group-O sensitized cell reagent, and especially of one using the patient's own red cells in clarifying the problems which arise as to the mechanism of the test.

Any hypothesis put forward to explain the mechanism of the Waaler-Rose test must take into account the fact that the patient's own red cells can replace those of sheep. 


\section{Summary and Conclusions}

(1) The observation has been confirmed that the Waaler-Rose test may be carried out with human red cells sensitized by a rabbit $v$. human amboceptor in the same dosage ( $\frac{1}{4}$ M.A.D.) as is used in the original test.

(2) The patient's own red cells sensitized and washed are agglutinated in the same way as sensitized cells from any group-O $\mathrm{Rh}$ negative human, indicating that iso-antibodies have no part in the reaction.

(3) As with the sheep cell system, the patient's serum activity resides in the euglobulin fraction.

(4) Absorption of the serum effect by the use of sensitized cells is difficult to achieve. In the present work the authors were partially successful when multiple serial absorptions were carried out on the same serum sample, or when the dose of sensitizer was increased above that used in the test. The absorption effects were unlike those associated with simple antigen-antibody reactions.

We are indebted to Miss P. P. Walpole for her valuable technical assistance in all stages of this work.

\section{REFERENCES}

Bunim, J. J., Sokoloff, L., Williams, R. R., and Black, R. L. (1955). J. chron. Dis., $1,168$.

Dickgiesser, F., and Harter, F. (1953). Z. ges. exp. Med., 122. 221.

Heller, G., Jacobson, A. S., and Kolodny, M. H. (1949). Proc. Soc. exp. Biol., 72, 316 .

, and Kammerer, W. H. (1954). J. Immunol., 72, 66. , - , and Schuman, R. L. (1952). Ibid., 69, 27

Kolodny, M. H., Lepow, I. H., Jacobson, A. S., Rivera, M. E. and Marks, G. H. (1955). Ibid., 74, 340.

Hobson, D., and Gorrili, R. H. (1952). Lancet, 1, 389.

Jochem, E., Eyquem, A., and Jacqueline, F. (1955). Ann. Inst. Pasteur, 88, 625.

Loghem-Langereis, P. E. van (1950). "Serological Reactions in Rheumatic Disease". Thesis, Amsterdam.

Pike, R. M., Sulkin, S. E., and Coggeshall, H. C. (1949). J. Immunol., 63, 441, 447 .

Robinson, A. R., Stulberg, C. S., and Kuyper, A. C. (1954). Proc. Soc. exp. Biol., 85, 4

Rose, H. M., Ragan, C., Pearce, E., and Lipman, M. O. (1948). Ibid., 68, 1 .

Svartz, N., and Schlossmann, K. (1953). Acta med. scand., 146, 313 Tawil, G. S., and Abd el Wahab, E. M. (1955). Amer. J. clin. Path., $25,166$.

Waaler, E. (1940). Acta path. microbiol., scand., 17, 172.

Wager, O. (1950). Ann. Med. exp. Biol. Fenn., 28, Suppl. 8.

W, and Alameri, E. (1953). Ibid., 31, 361.
Winblad, S. (1952). Acta med. scand., 142, 458.

Ziff, M., Brown, P., Badin, J., and McEwen, C. (1954). Bull. rheum. Dis., 5,75.

La réaction de Waaler-Rose modifiée, employant des globules humains sensibilisés

RÉSUMÉ

(1) On confirme l'observation que la réaction de Waaler-Rose peut être exécutée avec des globules rouges humains sensibilisés par un ambocepteur lapin antihumain avec la même dose (un quart de la dose minime agglutinante) qu'on utilise dans la réaction originale.

(2) Les propres globules rouges du malade, sensibilisés et lavés, sont agglutinés de la même manière que les globules sensibilisés de n'importe quel groupe humain $\mathrm{O}$, Rh-négatif, ce qui indique que les anticorps homologues ne participent pas à la réaction.

(3) Comme dans la méthode utilisant les globules de mouton, l'activité du sérum du malade réside dans la fraction d'euglobuline.

(4) L'absorption de l'effet du sérum par l'emploi de globules sensibilisés est difficile. Dans ce travail particulier les auteurs eurent des succès partiels en exécutant des absorptions multiples en série sur le même prélèvement, ou bien en excédant la dose habituelle du sensibilisateur. Les effets de l'absorption ne ressemblaient pas à ceux associés à de simples réactions entre l'antigène et l'anticorps.

La reacción de Waaler-Rose modificada, empleando globulos humanos sensibilizados

\section{Sumario}

(1) Se confirma la observación que la reacción d尺̂ ç Waaler-Rose puede ejecutarse con glóbulos rojos humanos sensibilizados por un amboceptor de conejळ antihumano con la misma dosis (un cuarto de la dosis mínima aglutinante) que se suele emplear en la reacción original.

(2) Los propios glóbulos rojos del enfermo, sensibilizados y lavados, se aglutinan de la misma manera que los glóbulos de cualquier grupo humano $\mathrm{O}, \mathrm{Rh}$ negativo, lo que indica que los iso-anticuerpos no participan en la reacción.

(3) Como en el sistema de glóbulos de oveja, la actividad del suero del enfermo mora en la fracción de euglobina.

(4) La absorción del efecto sérico por el empleo de glóbulos sensibilizados se alcanza con dificuldad. En este trabajo los autores tuvieron éxito parcial, ejecutando absorciones multiples seriales sobre el mismo especimen sérico o excediendo la dosis habitual del sensibilizador. Los efectos de la absorción no se parecían a los asociados a simples reacciones entre el antígeno y el anticuerpo. 